\title{
Improving the Speaking Skill by Vlog as Learning Media for Teaching Long Functional Text for Eighth Grade Students at SMPN 17 Medan
}

DOI: https://doi.org/10.47175/rielsj.v1i3.144

\section{| Khairunnisa br. Batubara ${ }^{1,{ }^{*}} \mid$ Christine Helena Natali ${ }^{2}$ |}

1,2 Faculty of Languages and

Arts, Universitas Negeri

Medan, Medan, Indonesia

*khaibara@unimed.ac.id

\begin{abstract}
This research was aimed to develop Video Blog as media of speaking in teaching long functional text for eighth grade students at SMPN 17 Medan. This research applied Research and Development (R\&D) model proposed by Gall, Gall and Borg (2003) through six procedures: gathering data and information, conducting need analysis, designing, expert validating, revising, and producing final product. The subjects of this research were 30 students of eighth grade of SMPN 17 Medan. The instruments of collecting data were the teacher's lesson plan, teacher's interview and students' questionnaires result. The data were analyzed by using descriptive analysis. The product has been validated by two experts. The assessment from the first expert was 4,5 or $91,3 \%$ while the assessment from the second expert was 4,6 or $93 \%$. Based on the experts' judgment result, the research showed that: The Video Blogs were eligible and valid as learning media in teaching and learning speaking long functional text for eighth grade students at SMPN 17 Medan. Furthermore, the video blogs give many benefits for students, such as to improve their speaking, make them enjoy and easier to speak long functional text. It means that the vlog media development was appropriate for the eighth grade students of SMPN 17 Medan.

KEYWORDS

Research and Development (R\&D); speaking; Long Functional Text; Video Blog
\end{abstract}

\section{INTRODUCTION}

Language has an important role in human activities to communicate, express the ideas, feeling, and desire with other people. It can be done through many languages, for example, in English. English is one of the languages that should be mastered in this modern era because English as International language is used in many countries as a tool to communicate globally. Therefore it is used in almost every aspects of life such as in science, education, technology and news.

Speaking is one of important skill in learning English for students to be develop. According to Richards (2008), English as Foreign language, students have to master speaking skill in English as our priority. Indonesia as a develop country realize the importance of speaking English. That's why in Indonesia, English lesson also put in the curriculum. The purpose of speaking English is challenging but in fact most of students did not want to learn it because they thought that speaking is difficult and uninteresting.

Based on the observation had done in SMPN 17 Medan the teachers were not appropriately teaching speaking skill. One of the factor is the lack of teaching media and 
materials that can help students to learn English in order to develop their speaking skills, and teacher tent to taught the students monotonously. Many students are not interested or motivated in learning speaking because students learn speaking by listening explanations and using white boards and markers, so students are not creative and active in learning speaking.

Another problem was the students do not show their cooperation besides students were lack of vocabulary. As we know that speaking needs a practice, so students effectively practice with others in their class. In turn, they felt shy to talk in front of the class. They just keep silent because they were not confident and fluent when speaking in front of the class, they also miss pronounce and difficult to express their idea when speaking. This problem is not just a problem to students, but also a problem for teachers. Because teachers are supposed to be creative in designing teaching learning process in English, especially to improve the students' speaking skill.

According to (Curriculum, 2013), states that "teachers will be more creative, while students will be more active". It means teachers are supposed to be creative in developing media in teaching that can make the students producing sentences or to improve the students' speaking skill.

Students as the millennial generation are comfortable with technologies that recent for older generations have grown up in the current environment of ubiquitous mobile communication. Therefore, teachers now should follow the latest technology and the internet in order that teachers understand what makes students interested. Besides, technology can help teacher and be facilitate in transferring knowledge to the students in many ways. Harmer (2001) argues that it is essential for teachers to develop speaking by means of interesting and relevant activities, in a contextualized manner, and related with the communicative necessities of the given population. He adds that teaching speaking should be taught in attractive and communicative activities.

To reach good atmosphere, improve their skill, and make the students interest in lesson, many activities can be used especially in this modern era of technology. One of them is designing media that make them have challenging and active to create and develop creative ideas toward their English speaking activities. There are many kinds of media that usually used in teaching. According to Thomas (cited in Rakhmania and Kusumaningrum, 2009), doing the online videos offers learners the opportunity to practice their language speaking skill anywhere and with little prior preparation, which keeps them involved in the process. The teachers and students delighted to teach and learn using the basic concept of technology.

Audio visual media, especially Video Blog are definitely acknowledged as one of the most effective tools in education. Video Blog (Vlog) has a lot potential and if tapped correctly creates wonders. Mustikawati (2013) in her study state that the use of video in teaching speaking for eighth grade students can stimulate students' interest and motivation in learning materials. By creating a Video Blog as the developing of media which is an interesting and innovative media can guiding students to practice speak in English more. Video Blog (Vlog) is not only give impact in improving speaking ability but also hopefully contribute to build students' enthusiasm in learning English generally and speaking long functional particularly. This study tries to analyze how are the video blogs (Vlog) developed as media in teaching long functional texts for eighth grade students at SMPN 17 Medan. 


\section{LITERATURE REVIEW}

English is divided into two skills; they are productive skills and receptive skills. One of the productive skills in English teaching-learning process is speaking.

Brown (2001) states that speaking as an interactive process of constructing meaning that involves producing, receiving, and processing speech sounds as main instruments. In addition, Combelet and Carter propose (2001:17) speaking is not just making sound though birds, animal, babies, make sound and though it may be communication of sorts. It is not speaking". From the definition above it explains that not all of the sounds produce from the mount is speaking. All the sounds produced by the mount called as speaking if the sound has a certain meaning.

Teaching speaking as the productive skill aims to make students can express their thoughts, feelings, ideas by having an oral communication. The way of teacher in teaching speaking also becomes one of the factors to improve students' speaking skill.

Nowadays, media has been one of important aspects for teachers to teach and to reach the goal of the learning process. Briton (2001:461) states that media can motivate students by bringing slice of the real life into the classroom and by presenting language in its complete communicative context. It called as a learning media if it could bring the messages to achieve the learning objectives. So, teacher needs not only an appropriate method and techniques but also an appropriate media in teaching speaking in order to make students feel interested to learn English. By understanding the aim of teaching speaking, teacher is expected to be able to create the good atmosphere in learning speaking at class and also being able to design speaking media that can cover not only students' speaking skill but also attract students' attention to keep learning English.

Shortly, it can be concluded that media are tools, materials, or events which establish conditions used by a teacher to facilitate the instruction to acquire knowledge, skill and attitudes and engage the learners in a topic or as the basis of a whole activity.

Video blog is a kind of media. Video blog is the audio-visual media classification that includes videos, films, slide-tape, programs and television. Video Blog have same characteristics that can enhance students/ skill including speaking. According to Felix and Stolarz (2006, p.17) the characteristics of video blog covers: (1) Video Blog are thematic. Each video blog has its own style, so an appropriate viewer tends to form around the video blog. The style is something that differentiates each video blog. (2) Video blog are episodic and permanent. Each video blog post has a specific date and time which make the viewers are easy to follow. (3) Video blog are subscribable.

There are many positive outcomes that every English teacher can harness from video blog in teaching speaking. Greenberg and Zanetis (2012, p.5) stated that video blog is an essential medium since it enables students to replay, rewind, stop, fast-forward the video until the fully understand the content. It makes students can open that video and practice speaking anywhere, moreover they are more confident in learning because they have more control over their own learning pace, students' involvement and motivation will be increased.

Besides, the implementations in learning speaking through vlog has weaknesses, such as the students should have adequate facilities like smartphones, laptops or computer and good internet connection.

Based on the explanation above, video blog is appropriate for students in learning speaking especially for learning long functional text. 


\section{RESEARCH METHODS}

This research was conducted by using educational research and development (R\&D) method that functioned to develop a new product which systematically field-tasted, evaluated and refined to meet a specified criteria of effectiveness, quality or similar standard. It adapted R \& D research method proposed by Borg and Gall (2003:569). Specifically of the procedures were: gathering data and information, conducting need analysis, designing, expert validating, revising, and producing final product.

\section{Subject of the Research}

The subject of this study will be 30 students of eighth grade students of SMPN 30 Medan, located in Jl. Bunga Raya Asam Kumbang Medan. The reason why this school will be chosen because based on the observation the researcher found that video blogs are never used as speaking media in this school.

\section{Techniques of Analyzing Data}

The data of this study is students' need analysis. The data is analyzed to answer students' problem and find appropriate teaching media in speaking long functional text. Then the data are used to develop a new teaching media.

The data will analyze as following:

1) Analyzing the teacher interview. The interview is administered to the teacher to gain information about media used from teacher's lesson plan and the teaching process.

2) Analyzing students' needs will be taken from interview and questionnaire.

3) Analyzing the existing of media related to students' need.

4) Developing Video Blog based on need analysis, core competence and basic competence of curriculum.

This research conducted by adapting Borg, Gall and Gall's research theory (2003) with some modifications which proposes 6 steps of $\mathrm{R} \& \mathrm{D}$ cycle. The steps are the sequence from the starting point to the end of steps which finally produce a new product in form of media in teaching speaking. This media is interesting and appropriate for the grade VIII students of SMPN 30 Medan since it is based on students' needs.

\section{RESULTS AND DISCUSSION}

\section{Gathering Data and Information}

The researcher collected the information by observing curriculum, syllabus, lesson plan, textbook and what media that was used by the teacher. SMPN 17 Medan used curriculum 2013. There are some topics that has been discussed in the eighth grade students, they are: can, giving instruction, greeting card, comparative degree, descriptive text, past tense, recount text, notice, narrative text. To support teaching and learning process in the classroom, the teacher used textbook from the government as the main source and used picture as teaching media.

The respondents of this research were eighth grade students of SMPN 17 Medan consist of 40 students. The description of the respondents is presented in the table below: 
Table 1. Respondents

\begin{tabular}{lcc}
\hline The total number & \multicolumn{2}{c}{ Gender } \\
\cline { 2 - 3 } of the respondents & Male & Female \\
$\mathbf{4 0}$ & 32 & 8 \\
\hline
\end{tabular}

\section{Conducting Need analysis}

After gathered the information from the first procedure, the researcher did the analysis. Need analysis was required before designing speaking media of long functional text. The researcher could get the students need which would be the priority of designing media with reference to the data from the analysis of teacher's interview and questionnaire for students.

\section{Questionnaire Analysis}

The questionnaire was distributed to students of SMPN 17 Medan on August 19 ${ }^{\text {th }}, 2019$. They were given a questionnaire which consisted of 12 questions. The questionnaire questions consist of three categories that need to be covered, namely necessities, lacks and wants of the learners. The three categories were presented in questions number 1,2,3,4,8,10 necessities, the questions number 5,6,7 lacks, and the questions number 9,11,12 wants.

The data were analyzed as guidance for designing video blog as speaking media of long functional text.

\section{Necessities of Speaking Media of Long Functional Text}

The necessities of the eighth grade students of SMPN 17 Medan about learning media related to learning English speaking. The table shows that there were 39 students or $97,5 \%$ have known the meaning of speaking itself, even though there was 1 student 2,5\% did not know yet. When they were asked about the difficulty in speaking there were 29 students or $72,5 \%$ said that speaking is average or medium. From the data above, the students ought to have good value of speaking. However, when they got test, just a few of them who got good value. After questionnaire analyzed, the researcher found that there were 30 students or $75 \%$ got difficulty and felt bored in speaking long functional text without media.

\section{Lacks of Speaking Media of Long Functional Text}

The lack of the grade eighth students of SMPN 17 Medan about learning media related to learning English speaking. There were 31 students or $77,5 \%$ said that speaking descriptive, recount, and narrative texts are difficult. Furthermore, 9 students or $22,5 \%$ said that speaking descriptive, recount, and narrative text are average or medium. While 1 student or $2,5 \%$ said that speaking descriptive, recount, and narrative text are easy. 33 students or $82,5 \%$ stated that the difficulty that they faced is difficult in making the explanation of something in general. The students' lack in speaking descriptive, recount, and narrative text are because of the lack of media. It is known from the students' questionnaire that there were 20 students or $50 \%$ said that the factor that make them difficulty in understanding descriptive, recount, and narrative text are the boring media. Besides, the other factors are the noisy class $25 \%$ or 10 students and the boring explanation $12,5 \%$ or 5 students. From this students lacks the researcher would develop the media that covered their difficulty. 


\section{Wants of Speaking Media of Long Functional Text}

32 students or $80 \%$ stated that to get good result in understanding speaking descriptive, recount, and narrative text needed courage media, it is video or audio visual media. This media brought the students to see pictures and hear the sound trough video, that's why they chose audio visual media.

\section{Interview Analysis}

There are some difficulties that students faced to achieve the goal of the teaching-learning process itself especially in speaking. They want to speak up but they didn't confident to do it. Some kinds of long functional text had been learnt in previous class, but they were still afraid to speak those kinds of text and didn't have any ideas of something to express. It is known from the teacher's interview.

The students need audio-visual media to help them understand the material discussed. They said that the media that they use before was boring and didn't enhance their ability in speaking skill. The researcher could identify their want of learning media which hoped enable them to understand the three genres of long functional text and speak it up. The teacher also expected this new learning media which is consist pictures and sounds that can help to understand it freely.

\section{Media Design}

Based on the need analysis, the next procedure that the researcher did was to develop the media. In developing video blog as teaching media, the researcher needed to choose the topic, prepare the contents used in the video and creating the video. Creating video was divided into video recording and audio recording. The second was editing process. After taking video was finished, then it edited by using video editor. In this research, the researcher used PowToon and Adobe Premier Pro as video editor. In this part the video was cut and mix with pictures and videos in order to produce the best video.

\section{Validating to Experts}

After the product was designed, the next procedure was validation by the experts. The media should be assessed and discussed with the experts to know if the media had been appropriate or not. It was also used to get suggestions, evaluations and comments in order to make the media be better and ready to be used. There were two experts that asked for validating the media. The first expert was Indra Hartoyo, S.Pd., M.Hum a lecturer from UNIMED, and the second expert was P. Sihombing, S.Pd an English lecturer from SMPN 17 Medan.

The assessment included four categories of dimension by using criteria from Rudianto cited from Yulihar (2016). The interval criteria of experts' assessment show below.

Table 2. Interval Criteria of Experts' Assessment

\begin{tabular}{cclc}
\hline No & Score & & Interpretation \\
\hline 1 & $0,00-2,49$ & Not Good & Not Appropriate \\
2 & $2,50-3,32$ & Enough & Less Appropriate \\
3 & $3,33-4,16$ & Good & Appropriate \\
4 & $4,17-5,00$ & Excellent & Very Appropriate \\
\hline
\end{tabular}

From the two assessments of validator, it shows the average score given is 4,5. It means that video blog as teaching media is considered as very appropriate. 


\section{Final Product}

The final product of this study was three videos blog for the eighth grade students of SMPN 17 Medan. They are descriptive text, narrative text, and the last is recount text. Those videos blog contained the explanation about definition, social function, generic structure and language features and some exercises such as analyze the generic structure and language features and etc. Here is the final products was ready to use.

The media can be accessed by students of eighth grade students of SMPN 17 Medan in academic year of 2019/2020. Based on the experts' judgment, the speaking media developed in this study are considered to be appropriate.

\section{CONCLUSION}

Based on the analysis, there is a problem that faced by teacher and eighth grade students of SMPN 17 Medan in teaching-learning long functional text. One of the problem is that the students are really difficult to speak up or express their idea in front of the class and lack of enthusiasm in learning long functional text. They are really lack of confident. In other hand, long functional text is really important to because they can express their idea widely in communication. Teacher needs an interesting media to help students in speaking long functional text. The solution is video blog media. It was design based on need analysis that using several procedures: (1) gathering data and information, (2) conducting need analysis, (3) media design, (4) validating to experts, (5) revision of the problem (6) final product. Furthermore, the average scores of media assessment were 4,6 or 93\% from English teacher and 4,5 or 91,3\% from English lecturer, which is it means that the videos blog media were categorized as very appropriate for students of eighth grade SMPN 17 Medan.

\section{Suggestions}

Based on the study of Developing Video Blog as Media of Speaking in Teaching Long Functional Text for Eighth Grade Students at SMPN 17 Medan the researcher would like to give suggestions that are elaborated as follows:

a. For Teachers

Since English language is one of the important subjects in Indonesia curriculum, teacher should be more creative as curriculum wants teacher do. Teachers have to make English class teaching and learning process goes well. The English interactive learning media can be used and optimized as additional sources in the teachinglearning process. The learning process can be successful if the teacher can explain the material to the students. Hopefully, the teaching-learning process will be interesting.

b. For students

The students are expected to prepare themselves and understand how to use this media before using it. They can use the media in every place because it is flexible, and they can use this media in speaking long functional text.

c. For other researchers

This research was trying to improve the quality of teaching and learning speaking long functional text by using video blog. May this media can be as example for other researcher in developing speaking media. 


\section{REFERENCES}

Longman.

(2003). The practice of English Language Teaching. New York:

Anderson, Mark and Kathy Anderson. (1997), Text Type in English, New York: Macilan

Arsyad, Azhar. 2002. Media Pembelajarn. Jakarta: PT Raja Grafindo Persada.

Brinton, Donna M. (2001). The Use of Media in Language Teaching in Marianne CelceMurcia (Eds). Teaching English as a Second or Foreign Languge (Third Ed). Boston, MA: Heinle \& Heinle.

Brown and Yule. (2012). The Function of Speaking. Accessed on April 17, 2018 fromhttp://funspeaking.blogspot.co.id/2012/11/the-function-of-speaking.html?m=1

Dirgeyasa, I Wy. (2016). College Academic Writing A Genre-Based Perpective. Jakarta: Kencana.

Dwiana, Ari Aprilia et. al. (2015). Improving Students' Speaking Skill Through Role Play Strategy At Grade Eighth In Smpn 6 Rambah

Felix, L., \& Stolarz, D. (2006) Video Blogging and Podcasting. Burlington : Elsevier Inc

Gall, M.D, Gall, J. P., \& Borg, W. R. 2003. Educational Research: An Introduction. 7th Edition. Boston: Pearson Education.

Gerot, Linda and Peter Wignell, Making Sense of Function Grammar, Australia: Gerd Stabler, 1994.

Greenberg, D. A., \& Zanetis J. (2012). The Impact of Broadcast and Streaming Video in Education. California: Cisco System Inc. Hung, S.-T.

Harmer, Jeremy. (2001). The Practice of English Language Teaching. Edinburgh Gate, Harlow: Pearson Education Limited.

Heaton, J. B. (1998). Aspect of speaking ability. New York: oxford university press.https://www.usd.ac.id/fakultas/pendidikan/f113/PLPG2017/Download/materi/bing /BAB-VIII-Description.pdf

Husein Rahmad \& Hollila Pulungan, Anni. (2017). Sumber Belajar Penunjang PLPG 2017 Mata Pelajaran/Paket Keahlian Bahasa Inggris. Kementerian Pendidikan dan Kebudayaan Direktorat Jenderal Guru dan Tenaga Kependidikan. Access on August 21, 2018

Hutchinson, Tom and Alan Waters. (1987). English For Specific Purposes. Cambridge: Cambridge University Press.

Hyland, Ken, Genre and Second Language Writing, The United State of America: The University of Michigan Press, (2004).

Kim, T. 2008. The CATESOL Journal. Accentedness, Comprehensibility, Intelligibility and Interpretability of NETS. 20(1).

Knapp, Peter and Megan Watkins. 2005. Genre, Text, Grammar. Technology for Teaching and Assessing Writing. University of New South Wales Press.

Mustikawati, (2013). The Effectiveness of Using Video in Teaching Speaking for the Eighth Grade Students of SMPN 1 Manisrenggo. A Thesis:

Nunan, David, Research Method in Language Learning, Cambridge: Cambridge University Press, 1993.

Nunan, David. (Ed). (2003). Practical English Language Teaching(1th Edition) Singapore McGraw-Hill/Contemporary.

Pardiyono. 2007. Pastibisa! Teaching Genre-Based Writing. Yogyakarta: ANDI

Rakjmanina Lisa \& Kusumaningrum, Dian, 2017. The Effectiveness of Video Blogging in Teaching Speaking Viewed from Students' Learning Motivation. ISELT.

Richard, J. C, and Renadya W. A (2002). Methodology in Language Teaching. Cambridge: Cambridge University Press 
Riswandi, D. (2016). Use of YouTube-Based Videos to Improve Students' Speaking Skill. Paper presented at the $2^{\text {nd }}$ International Conference on Teacher Training and Education, Sebelas Maret University.

Smaldino, S.E. Russel, J.D. Heinich, R. \& Molenda, M. (2004). Instructional Technology and Media for Learnig ( $8^{\text {th }}$ Edition). New Jersey: Pearson.

Sudjana, Nana and Ahmad Rifa'i. (2009). Media Pengajaran. Bandung: Sinar Baru Algesindo.

Suryani, (2015). The Effectiveness of Role Play in Teaching Speaking. ELTIN Journal, Vol 3. 